\title{
Correspondence
}

The Editor, Journal of Glaciology

SIR,

\section{Ice exposures in rock glaciers}

The presence of glacier ice as a significant feature in rockglacier development has been disputed by various authors (e.g. Haeberli, 1985; Barsch, 1987). This follows from the "conventional", interstitial ice (or "permafrost") theory of rock-glacier flow propounded by Wahrhaftig and Cox (1959). The debate about the formation and origin of rock glaciers has been discussed in these pages previously (Haeberli, 1989; Lliboutry, 1990), especially concerning the evidence presented by Johnson and Lacasse (1988). However, there are many examples which show that glacier ice can exist in rock glaciers. This has important consequences for our interpretation of these features, in terms of both the formative mechanisms and the environmental implications of their existence. Glacierice exposures have been described by authors such as Outcalt and Benedict (1965) and White (1975) at the Arapaho rock glacier in the Colorado Front Range, Potter (1972) in Wyoming and Calkin and others (1987) in Alaska as well as by Johnson and Lacasse (1988); Whalley and Martin (1992) give further examples. However, there have been no actual observations of glacier ice in more than one or perhaps two locations on any one rock glacier. Here we describe ice exposures in a small rock glacier in Nautárdalur, north Iceland.

The rock glacier is a small feature $(500 \mathrm{~m}$ long), typical in form (Fig. 1), situated at an altitude of about $1000 \mathrm{~m}$ in the Tröllaskagi Mountains, north Iceland. It lies below a plateau surface at about $1200 \mathrm{~m}$ a.s.l. and has a small cirque glacier, $300 \mathrm{~m}$ long, at its head. The rock glacier has the low surface velocities typically associated with rock glaciers; about $250 \mathrm{~mm} \mathrm{a}^{-1}$ measured over 16 years in this case. A previous description, including velocity data, has been given by Martin and Whalley (1987). In that paper, an exposure of glacier ice was described at the snout front, together with a small crevasse on the centre line, about $50 \mathrm{~m}$ from the snout (Fig. 1; positions 7 and 5, respectively). Other exposures have become visible in subsequent field seasons and their positions are also shown in Figure 1. In 1993, spring melt was very late and snow was still present, perhaps a month later than normally expected, with low temperatures until early August. Pits dug into the rock-glacier surface revealed frozen rocks and sediment at depths between 1 and $1.5 \mathrm{~m}$ below the surface. Of particular interest are the new exposures at 4 and 6 in Figure 1. Here, as at other

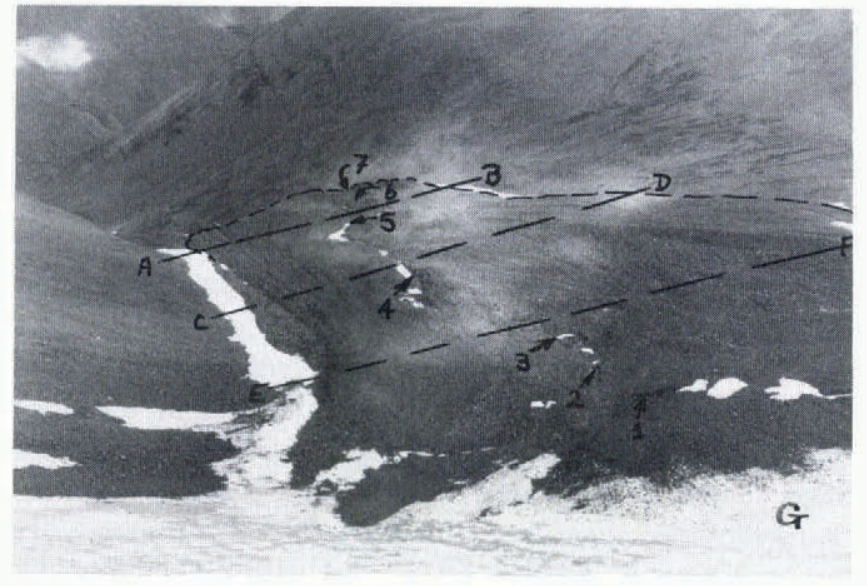

Fig. 1. The rock glacier in Nautárdalur (edges shown dashed for clarity), showing positions where glacier ice has been identified as well as the three traverse lines used for velocity determinations. $G$ is the present-day cirque glacier; 7 is the frontal exposure of ice described by Martin and Whalley (1987), and the line of exposures follows the "central furrow" of this rock glacier.

localities, ice-cemented debris was found above, as well as incorporated into massive glacier ice.

The upper exposure (4) shown in Figure 1 is about $100 \mathrm{~m}$ below the last trace of pure glacier ice in the cirque-glacier section. A meltwater stream flowed in a channel contained within the ice from the direction of the cirque glacier. The stream disappeared nearly vertically down into the rock glacier at this location (Fig. 2). The walls of both this exposure and that at the snout clearly

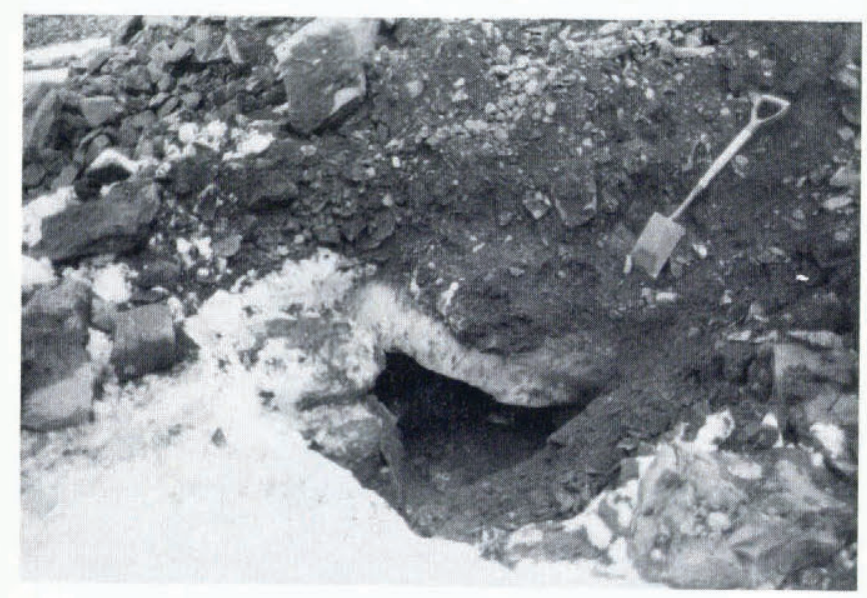

Fig. 2. An exposure of glacier ice at position 4, showing the cavity in which a meltwater stream flowed from right to left and descended further into the rock glacier. Frozen debris occurs above the exposed ice band at the level of the spade. 
showed banded ice dipping up-glacier between $22^{\circ}$ and $26^{\circ}$ containing debris bands up to $150 \mathrm{~mm}$ thick. These are directly comparable with the debris bands cropping out on the surface of the cirque-glacier section upstream of the rock glacier ( $\mathrm{G}$ in Fig. 1).

At the lower exposure (6 in Fig. 1; Fig. 3) it was possible to penetrate into a small cave. Inside (Fig. 4), two main facies could be seen:

i. On the left-debris-free, stratified ice consisting of large (generally $>10 \mathrm{~mm}$ ) crystals of ice. In the lower part of the lefthand wall the ice contained small $(<10 \mathrm{~mm})$ particles within stratified ice.

ii. On the right - debris frozen together with only a very little ice.

This cave, near the centre line of the rock glacier, and within the "central furrow", can be interpreted as showing glacier ice (left) merging with debris. The surface topography has changed markedly over the years at this location; as the ice near the central furrow melts, so rock debris becomes incorporated into the rock-glacier body in this part of the central furrow. Such changes do not seem unreasonable as it is about $30 \mathrm{~m}$ upstream from the exposure of glacier ice at the snout described by Martin and Whalley (1987).

We believe that the exposures at Nautárdalur indicate

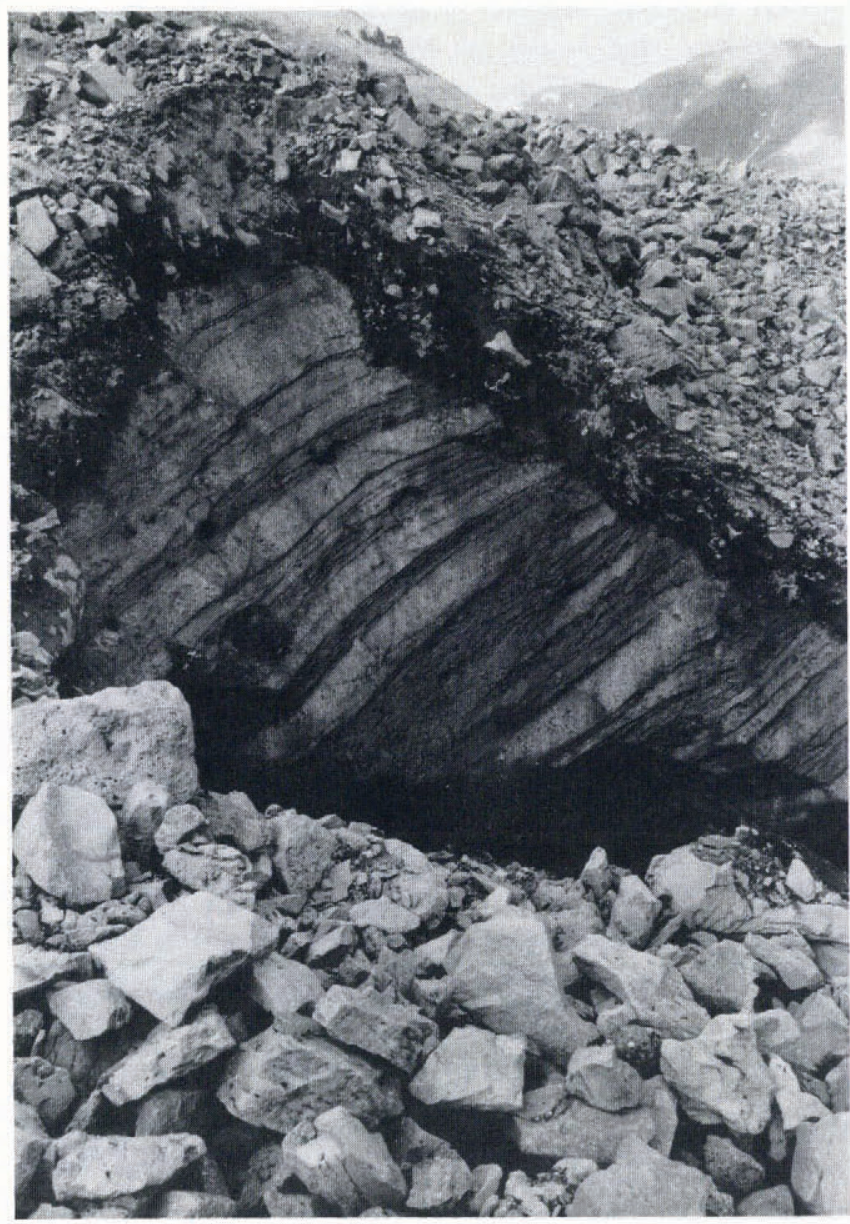

Fig. 3. An exposure of glacier ice (1990) $2 \mathrm{~m}$ high and about $30 \mathrm{~m}$ from the rock-glacier snout (to the right), showing the debris cover about $40 \mathrm{~cm}$ thick (position 6 in Fig. 1).
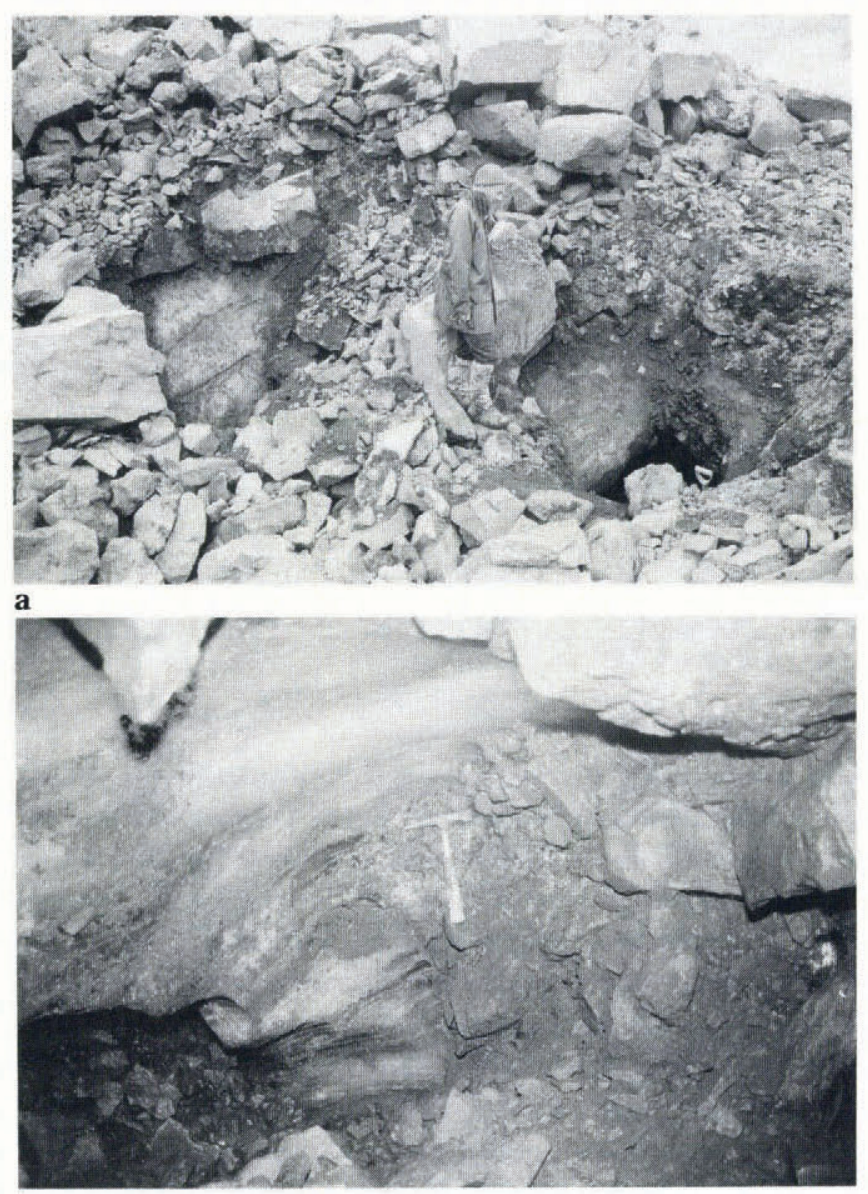

b

Fig. 4. a. The exterior position of the cave at location 6 in 1993; the small ice exposure to the left can be compared with that seen in 1990 (Fig. 3). b. The interior of the cave: stratified glacier ice is seen (left) joining frozen debris (right) derived from the rock glacier's surface.

a body of glacier ice continuous from the cirque glacier at the head through to the snout of the rock glacier. The ice banding and discrete layers of debris are indeed indicative of glacier ice as Outcalt and Benedict (1965) and Johnson and Lacasse (1988) argued. The frozen debris at and near the surface (Fig. 2) may be the result of the late spring and late penetration of summer warming. We have not observed such frozen debris before at Nautárdalur but it is a good example of the "superimposed" ice which can accumulate over a glacier ice core (Potter, 1972; Whalley, 1983). At Nautárdalur the superimposed ice probably melts during most summers. Thus, contrary to views that glacier ice cores cannot and do not exist in rock-glacier bodies, we now have direct evidence that they do. This is important as it allows a less restrictive interpretation of rock-glacier features and illustrates the importance of "hidden ice" in glacierized terrain (Whalley and others, 1986). Furthermore, it shows that an explanation of rockglacier behaviour must allow for their existence in association with temperate glacier bodies in marginally glacierized areas such as north Iceland.

\section{Acknowledgements}

We thank the various field teams and sponsors who have assisted on this project, especially the 1993 "Earthwatch" teams. 
School of Geosciences,

The Queen's University of Belfast,

Belfast BT7 $1 \mathcal{N N}$,

Northern Ireland

Scottish Natural Heritage,

2 Anderson Place,

Edinburgh EH6 5NP,

Scotland

10 January 1994

\section{REFERENCES}

Barsch, D. 1987. The problem of the ice-cored rock glacier. In Giardino, J.R., J.F. Shroder, Jr and J. D. Vitek, eds. Rock glaciers. London, Allen and Unwin, 45-53.

Calkin, P.E., L.A. Haworth and J.M. Ellis. 1987. Rock glaciers of central Brooks Range, Alaska, U.S.A. In Giardino, J.R., J.F. Shroder, Jr and J.D. Vitek, eds. Rock glaciers. London, Allen and Unwin, 65-82.

Haeberli, W. 1985. Creep of mountain permafrost: internal structure and flow of alpine rock glaciers. Eidg. Tech. Hochschule, Zürich. Versuchsanst. Wasserbau, Hydrol. Glaziol. Mitt. 77.
Haeberli, W. 1989. Correspondence. Glacier ice-cored rock glaciers in the Yukon Territory, Canada? J. Glaciol., 35(120), 294-295.

Johnson, P. G. and D. Lacasse. 1988. Rock glaciers of the Dalton Range, Kluane Ranges, south-west Yukon Territory, Canada. F. Glaciol., 34(118), 327-332.

Lliboutry, L. 1990. Correspondence. About the origin of rock glaciers. $\mathcal{F}$. Glaciol., 36(122), 125.

Martin, H. E. and W. B. Whalley. 1987. A glacier ice-cored rock glacier, Tröllaskagi, Iceland. Jökull, 37, 49-55.

Outcalt, S. I. and J. B. Benedict. 1965. Photo-interpretation of two types of rock glacier in the Colorado Front Range, U.S.A. F. Glaciol., 5(42), 849-856.

Potter, N., Jr. 1972. Ice-cored rock glacier, Galena Creek, northern Absaroka Mountains, Wyoming. Bull. Geol. Soc. Am., 83(10), 30253058 .

Wahrhaftig, C. and A. Cox. 1959. Rock glaciers in the Alaska Range. Bull. Geol. Soc. Am., 70(4), 383-436.

Whalley, W.B. 1983. Rock glaciers - permafrost features or glacial relics? In Permafrost; Fourth International Conference, fuly 17-22, 1983. Proceedings. Washington, DC, National Academy Press, 1396-1401.

Whalley, W. B. and H.E. Martin. 1992. Rock glaciers: II. Models and mechanisms. Prog. Phys. Geogr. 16(2), 127-186.

Whalley, W. B., H. E. Martin and A.F. Gellatly. 1986. The problem of "hidden" ice in glacier mapping. Ann. Glaciol., 8, 181-183.

White, S. E. 1975. Correspondence. Additional data on Arapaho rock glacier in Colorado Front Range, U.S.A. J. Glaciol., 14(72), 529-530.

The accuracy of references in the text and in this list is the responsibility of the authors, to whom queries should be addressed. 